\title{
A Study on the Teaching Mode of Advanced Mathematics Based on the Accreditation of Engineering Education*
}

\author{
Xiuli Li \\ School of Mathematics and Physics \\ Qingdao University of Science and Technology \\ Qingdao, China
}

\author{
Pengcheng Zhao \\ School of Mathematics and Physics \\ Qingdao University of Science and Technology \\ Qingdao, China
}

\author{
Hongyan $\mathrm{Li}$ \\ College of Electromechanical Engineering \\ Qingdao University of Science and Technology \\ Qingdao, China
}

\begin{abstract}
The professional certification of engineering education follows three basic concepts: outcome based, student centered and continuous improvement. These ideas are of great importance for field construction and educational reform, as well as the quality of personnel training in engineering education. It is of practical significance to guide the reform of China's engineering education with the concept of outcome based education. This paper, taking the Advanced Mathematics of "Process Equipment and Control Engineering" in our school as an example, explores the teaching mode of Advanced Mathematics under the background of engineering education's professional certification. The reform of class teaching mode and students' all-round ability in universities has been applied in practical teaching of "Process Equipment and Control Engineering" and gained good effects.
\end{abstract}

Keywords-engineering education's professional certification; outcome based education

\section{INTRODUCTION}

In 2013, China joined the Washington Agreement and began the professional certification of engineering education, which has international substantive equivalence. It follows three basic concepts: outcome based, student centered and continuous improvement. These ideas are of great importance for field construction and educational reform, as well as the quality of personnel training in engineering education. Outcome based education, short for OBE, holds that the goal of teaching design and teaching act are for the students' final learning outcomes through the process of education. It follows the principle of reverse design. Reverse design starts from demand (including internal demand and external demand), which determines training objectives, and

*This work is supported by high level team funding of Qingdao University of Science and Technology (Teaching team of basic Mathematics course in Science and Engineering). training objectives determine graduation requirements, by which curriculum system is decided. This paper, taking the Advanced Mathematics of "Process Equipment and Control Engineering" in our school as an example, explores the teaching mode of Advanced Mathematics under the background of engineering education's professional certification. The reform of class teaching mode and students' all-round ability in universities has been applied in practical teaching of "Process Equipment and Control Engineering" and gained good effects.

\section{Outcome Based, to Clear GoAl AND Purpose of TEACHING}

According to the requirements of engineering education's professional certification, teaching objectives must support one or several graduation requirements, and we should be aware of that to what degree the course contributes to certain graduation requirements. As a public basic course of Process Equipment and Control Engineering, Advanced Mathematics, based on calculus, includes calculus for functions with single variable, calculus for functions with several variables, space analytic geometry, ordinary differential equations and series. Through this course, students can gain a profound understanding on calculus. So at least it should be able to support the graduation requirements such as engineering knowledge, problem analysis and research. Meanwhile, as a public basic course, it should be preliminary to solve, analyze and study the complex problems of engineering in graduation requirements. This course is supposed to train students' ability to use math to solve engineering problems, and ability to use variable IT tools to search related material and study some contents independently, corresponding to the graduation requirements including using mathematical tools, modern technology, and lifelong learning. The support of other graduation requirements and indicators can be properly 
selected according to the characteristics of each school and major.

Training objective is the key factor that directly affects the training of students in universities. Engineering education certification requires personnel training not only to conform to the orientation of school running, but also to adapt to the social and economic development, and at the same time, the sustainable development of students should be taken into account. This requires a clear goal to be made according to the level, orientation, and future of personnel training. In the teaching of Advanced Mathematics, through the learning of function, limit, continuous, calculus for functions with single variable, differential equation, vector algebra and space analytic geometry, calculus for functions with several variables and series, we can achieve the following curriculum objectives in "Table I".

- To understand and grasp the basic concepts, characteristics and conclusions of Advanced Mathematics and have a proficient ability to fundamental operation.

TABLE I. The RELATION AMONG COURSE OBJECTIVES, GRADUATION REQUIREMENTS AND INDICATORS OF AdVANCED MATHEMATICS IN PROCESS EQUIPMENT AND CONTROL ENGINEERING

\begin{tabular}{|c|c|c|}
\hline Graduation Requirements & Indicators & Course Objectives \\
\hline \multirow[b]{2}{*}{$\begin{array}{l}\text { 1.Engineering Knowledge: able to use mathematical, } \\
\text { scientific, engineering and Process Equipment and } \\
\text { Control Engineering knowledge to solve complicated } \\
\text { problems. }\end{array}$} & $\begin{array}{l}\text { 1-1.To master and use mathematical } \\
\text { and scientific knowledge to express } \\
\text { complicated engineering problems }\end{array}$ & $1 、 2$ \\
\hline & $\begin{array}{l}\text { 1-2.To establish and choose } \\
\text { mathematical and mechanical models } \\
\text { for complex process or system, and } \\
\text { get answers through proper boundary } \\
\text { conditions }\end{array}$ & $2 、 3$ \\
\hline $\begin{array}{l}\text { 2.Problem Analysis: able to use mathematical, } \\
\text { scientific and Process Equipment and Control } \\
\text { Engineering principles to identify , express and } \\
\text { analyze complex problems, and get reasonable } \\
\text { conclusions. }\end{array}$ & $\begin{array}{l}\text { 2-1.To use mathematical, scientific } \\
\text { and Process Equipment and Control } \\
\text { Engineering principles to identify } \\
\text { and decide the important link and } \\
\text { parameters of complicated } \\
\text { engineering problems }\end{array}$ & $1 、 2 、 3$ \\
\hline $\begin{array}{l}\text { 4.Research: able to adopt scientific principles and } \\
\text { methods, and use theoretical analysis, document } \\
\text { research and experiments to study complicated } \\
\text { engineering problems, including designing } \\
\text { experiment, finishing experiment, analyzing and } \\
\text { explaining result, and getting reasonable conclusion. }\end{array}$ & $\begin{array}{l}\text { 4-3. To adopt scientific principles and } \\
\text { methods to design experiment, finish } \\
\text { experiment, collect and analyze } \\
\text { experimental data. }\end{array}$ & $1 、 2 、 3$ \\
\hline
\end{tabular}

- To be able to abstract and generalize practical problems with knowledge of Advanced Mathematics and to learn independently and do logic reasoning.

- To analyze and solve the practical problems of Process Equipment and Control Engineering with knowledge of Advanced Mathematics .

\section{REVERSE DESIGN, TO SET UP TEACHING CONTENT ACCORDING TO GRADUATION REQUIREMENTS}

Graduation requirements determine teaching contents, while teaching contents support to achieve the former. The correspondence between graduation requirements and teaching contents is different from the correspondence between graduation requirements and curriculum system, for the former is partial, which refers to the relationship between one or a few graduation requirements and one or a few courses, while the latter is overall. That is to say, we should implement graduation requirements one by one in syllabus of each course, so as to make clear the contribution of specific courses to graduation requirements. Outcome based teaching design requires that we should find out to which graduation requirements a course contributes at first, then determine teaching content according to corresponding requirements, and at last decide teaching hours needed to finish teaching content. The syllabus based on outcome is written in accordance with the entries involved in the graduation requirements (rather than the chapters of the textbook). The correspondence between graduation requirements and teaching contents provides a basis for deciding teaching content and teaching hours. In traditional education, teaching content and teaching hours are determined by teaching materials, while outcome based education breaks the barriers between courses, weakens the systematicness, integrity and continuity of the curriculum itself, and strengthens the links between the courses.

The teaching contents, methods and effects of Advanced Mathematics are closely related to the engineering ability of students of Process Equipment and Control Engineering, and play a vital role in the realization of training objectives. The basic idea of this course is to strengthen foundation, emphasize practice and highlight innovation. In the aspect of teaching content, not only the basic knowledge is highlighted, but also the examples and methods are introduced and applied. Focused on the engineering perspective of this major, learning from international education method and advanced teaching system, the curriculum knowledge system is optimized on the basis of the existing curriculum system by combining the characteristics of modern education.

Advanced Mathematics lay particular stress on theory, but in the course of teaching, while emphasizing theoretical learning, it also pay attention to the cultivation of students' engineering quality. In the course of teaching, the requirements of the professional certification of engineering education can be achieved through the following points. 
Firstly, we should pay attention to the explanation of the purpose, conclusion and application of theoretical deduction, so that students can grasp the reason and significance of the conclusion. Secondly, great attention must be paid to linking theory with practice by explaining the application of Advanced Mathematics in scientific study and life, such as the application of gradient and directional derivative. Thirdly, we should appropriately increase the mathematical experiment and design the experiment reasonably. As a public basic course, Advanced Mathematics can enhance students' understanding of theoretical part through some Matlab experiments, and encourage students to solve practical problems by using theoretical knowledge, so as to improve the ability of solving practical problems. In the course of teaching, we set up a teaching part to analyze engineering problems and mathematical modeling problems, so as to strengthen students' ability of management, teamwork and expression.

\section{Student Centered, to Improve Teaching METHODS}

A personnel training under engineering education certification is oriented to output and stresses transferring from "what teachers teach" to "what students are supposed to learn". Reverse design takes the training target and graduation requirements as the starting point and adopt reasonable teaching methods.

\section{A. Construct Dialogue-oriented teaching}

During lectures, teachers not only teach knowledge, but also guide students to think and ask questions. Teachers should set suitable questions, and activate classroom atmosphere through discussion. Taking Advanced Mathematics as example, teachers and students should learn teaching content system together, as well as graduation requirements and course goals. While teaching related theories, teachers put up questions, inspire and guide students to combine theory with life or learning experience; students are encouraged to ask questions and give suggestions towards teaching schedule and methods. Questions on class should be "less but better"; question design should be effective and conform to students' cognitive structure; the manner of asking questions are supposed to reflect students' subjective position. For example, students thinks curve integral and surface integral difficult so we can combine geometric meaning and physical meaning with the learning process to analyze and understand. In addition, we can add some cases according to university's feature. This dialogue is not confined to the classroom. Students and teachers can also discuss questions and teaching methods in chatting groups on QQ or Wechat.

\section{B. Construct an Open Teaching}

To fit students' interest and development, students' subjective position is guaranteed, the importance of students' development is reflected, courses of Mathematical Modeling and Mathematical Experiment are set up and introduced into Advanced Mathematics. An open learning mode is established, combined with cases, to provide students with basic experiments, selected experiments and open experiments, thus forming the practice part of Advanced Mathematics, and realizing the fusion of modern education and traditional education. The open teaching form of Advanced Mathematics insists that students are the subject of research and we should arouse students' strong thirst for knowledge and creativity, and cultivate their ability to put forward, analyze and solve problems. In addition, an open teaching form is to pay attention to group communication and cooperation thus changing the single form that only teacher himself talks on class. Students can choose the course of the teacher they like so as to increase interest in learning. What's more, taking courses of Process Equipment and Control Engineering as platform, surrounding the requirements of excellent course construction, we should actively promote the construction of online courses and make resources available online, so that students can arrange time and place flexibly to review or learn.

Open elements can also be added to the assessment of Advanced Mathematics. What important is "openness", which means that teaching act should not be confined to a test paper and standard answer, and students should be encouraged to do research. Traditional result-evaluation system is combined with process-evaluation system to form a new one. It can be divided into basic level and applied level. Students can choose corresponding evaluation level according to their respective conditions. (1) Basic level goes for all students. The final examination takes $70 \%$. Learning process is also taken account, with regular attendance taking $10 \%$, class performance taking $10 \%$ and homework taking $10 \%$. (2) Applied level evaluation system lay stress on students' all-round ability. Final examination only takes $50 \%$. The evaluation of learning process is the same with basic level, with regular attendance taking $10 \%$, class performance taking $10 \%$ and homework taking 10\%; research reports mainly examine students' ability to apply knowledge, taking $20 \%$.

\section{Construct Question-oriented Teaching}

Students are asked to preview, learn and review with questions. While previewing and looking up materials, they put forward their questions; in addition to get those questions' answers, in class, they are also supposed to put forward new questions towards teacher's lecture and teacher should deliberately left some questions to encourage students to think; after class, students are expected to think and study in depth while doing homework; besides final examination, analysis and research works are needed to impel students to look up information by oneself or in group so as that their research ability can be improved. We strive to encourage students to think and study, develop their habit of learning independently and actively, and improve their ability to discover, analyze and solve complicated problems through question-oriented teaching. By this way, students can bring together and apply knowledge of the whole course in a comprehensive way, so as to improve their ability to analyze and solve problems. 


\section{Construct Quality-oriented Teaching}

Engineering education professional certification requires that students should have not only ability to study independently and actively, ability to do design and research through modern IT tools while confronting complex engineering problems, but also a good quality and sense of social responsibility. In process of teaching Advanced
Mathematics, great attention is paid to develop students' ability to do, think and cooperate, to train their creativity and to cultivate their quality. We should teach students in accordance with their aptitude and pay attention to practice teaching and case teaching. The combination of theory and practice is emphasized as practice teaching is direct, practical and exploratory. Students' ability to express, communicate and write is trained through defense and paper report.

TABLE II. ThE ACHIEVEMENT OF AdVANCED MATHEMATICS TEACHING OBJECTIVES OF STUdENTS OF GRADE 2012 AND 2013 FROM PROCESS EQUIPMENT AND CONTROL ENGINEERING

\begin{tabular}{|c|c|c|c|c|c|c|}
\hline \multirow{3}{*}{ Graduation Requirements } & \multirow{3}{*}{ Indicators } & \multirow{3}{*}{$\begin{array}{c}\text { Course } \\
\text { Objectives }\end{array}$} & \multicolumn{4}{|c|}{ Achievement of Teaching Objectives } \\
\hline & & & \multicolumn{2}{|c|}{ Grade 2012} & \multicolumn{2}{|c|}{ Grade 2013} \\
\hline & & & $\begin{array}{c}\text { Exam } \\
(100 \%)\end{array}$ & $\begin{array}{c}\text { Degree of } \\
\text { Achievement }\end{array}$ & $\begin{array}{c}\text { Exam } \\
(100 \%)\end{array}$ & $\begin{array}{c}\text { Degree of } \\
\text { Achievement }\end{array}$ \\
\hline \multirow{2}{*}{$\begin{array}{l}\text { 1.Engineering Knowledge: able to use } \\
\text { mathematical, scientific, engineering } \\
\text { and Process Equipment and Control } \\
\text { Engineering knowledge to solve } \\
\text { complicated problems. }\end{array}$} & $\begin{array}{l}\text { 1-1.To master and use mathematical } \\
\text { and scientific knowledge to express } \\
\text { complicated engineering problems }\end{array}$ & $1 、 2$ & $1 、 2$ & 0.753 & $1 、 2$ & 0.635 \\
\hline & $\begin{array}{l}\text { 1-2.To establish and choose } \\
\text { mathematical and mechanical models } \\
\text { for complex process or system, and get } \\
\text { answers through proper boundary } \\
\text { conditions }\end{array}$ & $2 、 3$ & 5 & 0.857 & 5 & 0.582 \\
\hline $\begin{array}{l}\text { 2.Problem Analysis: able to use } \\
\text { mathematical, scientific and Process } \\
\text { Equipment and Control Engineering } \\
\text { principles to identify, express and } \\
\text { analyze complex problems, and get } \\
\text { reasonable conclusions. }\end{array}$ & $\begin{array}{l}\text { 2-1.To use mathematical, scientific and } \\
\text { Process Equipment and Control } \\
\text { Engineering principles to identify and } \\
\text { decide the important link and } \\
\text { parameters of complicated engineering } \\
\text { problems }\end{array}$ & $1 、 2 、 3$ & $6 、 7$ & 0.551 & $6 、 7$ & 0.479 \\
\hline $\begin{array}{l}\text { 4. Research: able to adopt scientific } \\
\text { principles and methods, and use } \\
\text { theoretical analysis, document } \\
\text { research and experiments to study } \\
\text { complicated engineering problems, } \\
\text { including designing experiment, } \\
\text { finishing experiment, analyzing and } \\
\text { explaining result, and getting } \\
\text { reasonable conclusion. }\end{array}$ & $\begin{array}{l}\text { 4-3.To adopt scientific principles and } \\
\text { methods to design experiment, finish } \\
\text { experiment, collect and analyze } \\
\text { experimental data. }\end{array}$ & $1,2 、 3$ & 3、 4 & 0.657 & $3 、 4$ & 0.688 \\
\hline
\end{tabular}

V. Sustainable DeVelopment, to Establish an EVALUATION MECHANISM OF CURRICULUM OBJECTIVES

A very important idea of engineering education professional certification is continuous improvement. According to the requirements of engineering education assessment, we need to evaluate the achievement of graduation requirements in a certain period and the standard is examination result. A course supports a number of graduation requirements. Whether the examination method can completely reflect the evaluation of corresponding graduation requirements, whether the assessment form is appropriate, and whether its judgment is strict or not are the most basic standard for the evaluation of this course. Therefore, the assessment form and content should be designed appropriately according to the requirements that one course supports. At last, the degree of realization of related requirements is regarded as the basis of further improvement. Therefore, after final exam, we put all students' score of each question into Excel table, according to the graduation requirements and indicators. "Table II" is the achievement evaluation table of Advanced Mathematics, whose data is from students of grade 2012 and 2013. Degree of achievement=average value/expected value. Average value is the average of all students' score in that year while expected value is the full score of a teaching activity against an indicator. Taking Advanced Mathematics as an example, it has some indicators, one of which is $1-1$. If its full mark is 30 points, while its average value is 22.593 , then the achievement of this indicator is $40 / 30=0.7531$.

\section{CONCLUSION}

To improve quality of education is the eternal theme of higher education. In the background of engineering education accreditation, we break the chain of traditional education and constantly improve our teaching mode by discussing teaching content and method and introducing the mode of "evaluate-improve-reevaluate". The course is well applied to all students and gains a good effect. In recent years, students of Process Equipment and Control Engineering showed excellent performance in mathematical modeling and competitions. The facts show that the transformation of teaching mode is effective and plays an important role in improving students' all-round quality. "Table III", and "Table IV" show the prizes our students have gained in recent years. 
TABLE III. The Mathematical Modeling Prizes Gained By STUDENTS FROM PROCESS EQUIPMENT AND CONTROL ENGINEERING IN QINGDAO UNIVERSITY OF SCIENCE AND TECHNOLOGY

\begin{tabular}{|c|c|c|c|c|}
\hline Year & $\begin{array}{c}\text { The first } \\
\text { prize at } \\
\text { provincial } \\
\text { level }\end{array}$ & $\begin{array}{c}\text { The second } \\
\text { prize at } \\
\text { provincial } \\
\text { level }\end{array}$ & $\begin{array}{c}\text { The first } \\
\text { prize at } \\
\text { national } \\
\text { level }\end{array}$ & $\begin{array}{c}\text { The second } \\
\text { prize at } \\
\text { national level }\end{array}$ \\
\hline 2014 & 2 & 2 & 0 & 0 \\
\hline 2015 & 2 & 1 & 0 & 0 \\
\hline 2016 & 1 & 3 & 0 & 1 \\
\hline 2017 & 2 & 3 & 0 & 1 \\
\hline
\end{tabular}

TABLE IV. The MATHEMATICAL COMPETITION PRIZES GAINED BY STUDENTS FROM PROCESS EQUIPMENT AND CONTROL ENGINEERING IN QINGDAO UNIVERSITY OF SCIENCE AND TECHNOLOGY

\begin{tabular}{|c|c|c|c|c|}
\hline Year & $\begin{array}{c}\text { The first } \\
\text { prize at } \\
\text { provincial } \\
\text { level }\end{array}$ & $\begin{array}{c}\text { The second } \\
\text { prize at } \\
\text { provincial } \\
\text { level }\end{array}$ & $\begin{array}{c}\text { The first } \\
\text { prize at } \\
\text { national } \\
\text { level }\end{array}$ & $\begin{array}{c}\text { The second } \\
\text { prize at } \\
\text { national level }\end{array}$ \\
\hline 2014 & 1 & 2 & 0 & 0 \\
\hline 2015 & 1 & 3 & 0 & 0 \\
\hline 2016 & 2 & 2 & 0 & 1 \\
\hline 2017 & 1 & 4 & 1 & 1 \\
\hline
\end{tabular}

\section{REFERENCES}

[1] Wang Junfei, "The Research on Teaching Content of Advanced Mathematics under Engineering Education Professional Certification", Value Engineering, vol. 23, pp. 255-258, 2017.

[2] Jiang Haili, Sun Qiuhua, and Zhao Yancheng, "The Research on Engineering Case Teaching Mode under Engineering Education Professional Certification", Heilongjiang Researches on Higher Education, vol. 2, pp. 162-164, 2017.

[3] Mu Lihua, Wang Junfei, and Feng Yutie, "How to Teach the First Economic Mathematics Class under Engineering Education Professional Certification", China Economist, vol. 5, pp. 242-243, 2015.

[4] Hu Wenlong, "Teaching Development of Teachers in Universities under Engineering Education Professional Certification", Research in Higher Education of Engineering, vol. 1, pp. 73-78, 2015.

[5] Liu Bao, Li Zhengang, and Ruan Boxing, "Reform of College Teaching Mode under Engineering Education Professional Certification", Heilongjiang Researches on Higher Education, vol. 2, pp. 157-160, 2017.

[6] Li Zhiyi, "The Research on OBE of Engineering Education Professional Certification", China Higher Education, vol. 17, pp. 7-10, 2014.

[7] An Shiao, "The Design and Application of Dialogue-oriented Teaching Mode based on Cases", China Higher Education Research, vol. 3, pp. 83-87, 2017.

[8] Zhang Yunyan, "Discussion on the Function of Open Teaching in Advanced Mathematic", Journal of Educational Institute of Jilin Province, vol. 10, pp. 112-113, 2011(10). 